\title{
Analisis Efektifitas Penggunaan Metode Kooperatif Tipe Learning Together pada Pembelajaran PAI di SMP AI Mahrusiyah Ngampel Kediri
}

\author{
Rinto Arahap ${ }^{1,}$ Makhromi ${ }^{2}$ \\ ${ }^{1,2}$ Institut Agama Islam Tribakti (IAIT)Kediri \\ Iarahaprintorinto@gmail.com, ${ }^{2}$ makhromighufta@gmail.com
}

\begin{abstract}
This research on in the big topic of learning technology. The researcher tries to reveal the cooperative method of learning together type which is implemented in Al Mahrusiyah Junior High School in Kediri on the subject of Islamic Religious Education. The cooperative method of learning together type is used as a solution so that the class can be effective so that the objectives of learning can be achieved. The objectives of this study are (1) To reveal the effectiveness of the cooperative method of learning together type in SMK Al Mahrusiyah. (2) To reveal the impact of the cooperative method of learning together type in SMK Al Mahrusiyah. This research is a descriptive qualitative study using verbal data and analyzed by the source triangulation method. The results of the research are (1) The cooperative method of learning together type is felt to be implemented effectively with evidence of an increase in the value above the KKM value, (2) The impact arising from the application of the cooperative method of learning together is that students are more active.
\end{abstract}

Key Word: Cooperative Learning, Learning Together Type, Islamic Education

\begin{abstract}
Abstrak
Penelitian ini dalam topik besar teknologi pembelajaran. Peneliti berupaya mengungkap metode kooperatif tipe learning together yang dilaksanankan di SMP Al Mahrusiyah Kota Kediri pada mata pelajaran Pendidikan Agama Islam (PAI). Metode kooperatif tipe learning together digunakan sebagai solusi agar kelas bisa efektif sehingga tujuan dari pembelajaran dapat tercapai. Tujuan penelitian ini adalah (1) mengungkap efektifitas metode kooperatif tipe learning together di SMP Al Mahrusiyah (2) mengetahui dampak metode kooperatif tipe learning together di SMP Al Mahrusiyah. Penelitian ini merupakan penelitian kualitif deskriptif dengan data verbal dan dianalisis dengan metode triangulasi sumber. Hasil dari penelitian yaitu, (1) metode kooperatif tipe learning together dapat dilaksanakan secara efektif dengan bukti peningkatan nilai di atas nilai Kriteria Ketuntasan Minimun (KKM), (2) dampak yang ditimbulkan dari penerapan metode kooperatif tipe learning together adalah siswa lebih aktif.
\end{abstract}

Kata Kunci: Pembelajaran Kooperatif, Pendidikan Agama Islam, Tipe Pembelajaran Bersama 


\section{Pendahuluan}

Efektifitas pembelajaran menjadi salah satu unsur untuk mengukur atau mengetahui tingkat ketercapaian tujuan pembelajaran. Dengan kata lain, dapat juga dikatakan sebagai ketepatan guru dalam mengelola situasi pembelajaran. Menurut Rohmawati, efektifitas pembelajaran adalah indikator atau persentase keberhasilan dari sebuah proses interaksi antara siswa dengan guru dalam kegiatan pembelajaran yang mengacu pada tujuan pembelajaran. ${ }^{1}$ Definisi lain efektifitas pembelajaran menurut Saregar adalah interaksi pada proses pembelajaran yang akan memberikan dampak pada keberhasilan seorang mentor atau guru terhadap hasil belajar siswa. ${ }^{2}$

Salah satu cara yang dapat digunakan untuk mengetahui efektifitas suatu pembelajaran yaitu dengan melihat pengaruhnya pada siswa. ${ }^{3}$ Tidak hanya itu, efektifitas pembelajaran juga dapat dilihat dari tingkat intensitas aktifitas siswa saat pembelajaran berlangsung. Misalnya, bagaimana respon siswa pada materi yang sedang diberikan oleh guru serta bagaimana penguasaan konsep yang telah diterima

\footnotetext{
1 Afifatu Rohmawati, "Efektivitas Pembelajaran," Jurnal Pendidikan Usia Dini 9, no. 1 (2015): 15-32. 2 Antomi Saregar, "Efektivitas Model Pembelajaran Cups: Dampak Terhadap Kemampuan Berpikir Tingkat Tinggi Peserta Didik Madrasah Aliyah Mathla'ul Anwar Gisting Lampung," Jurnal Ilmiah Pendidikan Fisika Al-BiRuNi 5, no. 2 (Oktober 2016): 234-43.
}

siswa. Agar suatu konsep pembelajaran bisa efektif, maka perlu adanya interaksi timbal balik antara peserta didik dan guru. Hal tersebut agar tujuan pembelajaran bisa tercapai. ${ }^{4}$

Berdasarkan pengertian di atas, dapat dipahami bahwa pembelajaran yang efektif merupakan sebuah proses pembelajaran yang mampu memberikan nilai lebih atau informasi baru dan dibutuhkan siswa. Pembelajaran juga bisa dikatakan efektif apabila dari proses pembelajaran tersebut dapat memberikan sebuah informasi dan pengetahuan siswa dan juga menambah tingkat keaktifan siswa untuk mencari informasi selain dari guru.

Menurut Thomas F. Staton dalam how to instrucy succesfully, yang dikutip oleh Yunus Yamasa menyampaikan bahwasannya ciri - ciri dari metode yang efektif antara lain: ada motivasi belajar siswa, menjaga tingkat perhatian atau focus sepenuhnya, meningkatkan kegiatan mental..$^{5}$

Adapun learning together yaitu sebuah proses belajar dengan membentuk beberapa kelompok siswa di mana dalam

\footnotetext{
3 Muhammad Fayakun, "Efektivitas Pembelajaran Fisika Menggunakan Model Kontekstual (CTL) Dengan Metodepredict, Observe, Explain Terhadap Kemampuan Berpikir Tingkat Tinggi," Jurnal Pendidikan Fisika Indonesia 11, no. 1 (Januari 2015): 49-58.

${ }^{4}$ Rohmawati, "Efektivitas Pembelajaran."

5 Yunus Yamasa, Metodologi Pengajaran Agama Islam (Jakarta: Pustaka Firdaus, 2000). h. 114
} 
satu kelompok beranggotakan siswa dengan beragam karakter dan tipe yang ada dalam kelas tersebut. Metode ini termasuk metode kooperatif, di mana siswa berada dalam kelompok heterogen yang beranggotakan empat atau lima siswa untuk menyelesaikan suatu tugas yang diberikan oleh guru. ${ }^{6}$ Proses ini juga diartikan sebuah penyajian bahan ajar yang mana seorang guru memberi kesempatan kepada para siswa (beberapa kelompok siswa yang telah dibentuk) untuk membuat diskusi ilmiah sebagai sarana untuk mengumpulkan pendapat, kesimpulan dan mendapatkan bagaimana alternatif dari suatu masalah. ${ }^{7}$

Berbagai macam metode telah diciptakan dan diterapkan sebagai aspek penting dalam menangani masalah efektifitas pembelajaran. Dalam hal ini tidak hanya dibutuhkan metode saja, tetapi keterampilan dan kesiapan guru juga merupakan hal penting sehingga harus dipertimbangkan secara matang. Dalam proses belajar mengajar, seorang guru harus mampu menyampaikan materi dengan baik. Maka dari itu, guru harus mempersiapkan

${ }^{6}$ Zusi Hermawati, "Peningkatan Hasil Belajar Dan Keaktifan Pada Mata Pelajaran Matematika Melalui Model Pembelajaran Learning Together Siswa Sekolah Dasar," Jurnal Pendidikan Dasar 6, no. 1 (2018): 36-41.

${ }^{7}$ Abdul Majid, Strategi Pembelajaran (Bandung: PT Rosda Karya, 2013). h. 198

${ }^{8}$ Nur Laili, "Metode Learning Tournament Untuk Meningkatkan Kreativitas dan Hasil Belajar Siswa,"

Jurnal Konseling dan Pendidikan 4, no. 2 (Juni 2016): 20-28 metode yang akan diterapkan kepada siswa agar siswa dapat menerima informasi secara maksimal. Dengan begitu guru dapat menggunakan metode yang sesuai dengan siswa dan menyesuaikan dengan seiringnya perkembangan pembelajaran. ${ }^{8}$

Pada umumnya proses pembelajaran masih cenderung satu arah, yaitu guru selalu memberikan informasi kepada siswa tanpa adanya timbal balik dari siswa. Metode pembelajaran tersebut menjadikan kegiatan belajar mengajar menjadi monoton, seperti penggunaan metode ceramah yang terus menerus sehingga menyebabkan siswa lebih mudah bosan dan jenuh. ${ }^{9}$ Tidak dapat dipungkiri bahwa hal tersebut berimbas pada penyerapan siswa dalam menerima dan menyerap materi pelajaran tidak maksimal dan juga berimbas pada hasil belajar siswa yang menjadi rendah. ${ }^{10}$ Hal seperti ini pernah terjadi di SD Negeri Tetak 01. Di mana dalam proses pembelajarannya masih cenderung menggunakan metode ceramah secara terus menerus dan siswa tidak diberi kesempatan untuk berperan aktif seperti mencari materi atau informasi secara

${ }^{9}$ Agnia, "Metode Sosiodrama Berpengaruh Terhadap Motivasi Belajar Siswa," DIDAKTIKA TAUHID: Jurnal Pendidikan Guru Sekolah Dasar 4, no. 1 (2017): 1-9.

10 Sigit Sujatmika, "Pengaruh Metode Pembelajaran Problem Based Learning Terhadap Prestasi Belajar Ditinjau Dari Gaya Belajar Dan Kemandirian," Jurnal Sosiohumaniora 2, no. 1 (2016): 116-23. 
mandiri. Akhirnya ada beberapa siswa yang masih memiliki hasil belajar yang rendah. ${ }^{11}$

Metode ceramah tidak hanya memilik kelemahan yang menyebabkan siswa jenuh dan bosan tetapi metode ini mempunyai keunggulan tersendiri yaitu dan tidak banyak mengeluarkan biaya. Murah di sini yaitu tidak memerlukan alat yang lengkap sedangkan mudah yaitu, memang ceramah itu hanya mengandalkan suara guru. ${ }^{12}$ Dalam penelitian Fatmawati menemukan bahwa terdapat guru yang menerapkan metode ceramah dalam proses pembelajarannya untuk meningkatkan minat belajar siswa, di sini guru hanya menerangkan secara lisan dan sesekali memperagakan apa yang sedang ia terangkan. ${ }^{13}$

Untuk mewujudkan hasil belajar yang maksimal dan dapat menumbuhkan semangat dari peserta didik untuk belajar, maka diperlukan usaha-usaha dari tenaga pendidik yang profesional seperti bagaimana metode dan strategi dalam memberikan materi kepada para peserta didik. Sebagai seorang guru, dituntut untuk bisa

11 Prasetyo Widyanto, "Penerapan Metode Pembelajaran Group Investigation Berbantuan Media Flanelgraf Untuk Meningkatkan Minat dan Hasil Belajar Siswa Pada Mata Pelajaran IPA," JPDN: 118-29.

12 Jon Helmi, "Penerapan Konsep Silberman dalam Metode Ceramah pada Pembelajaran PAI," $A L$ ISHLAH: Jurnal Pendidikan 8, no. 2 (2016): 221-45. merupakan metode yang mudah diterapkan Jurnal Pendidikan Dasar Nusantara 3, no. 1 (2017):

menjalankan dan mengembangkan metode dan program pembelajaran yang optimal, aga proses belajar mengajar berjalan secara efektif dan efisien dan membrikan hasil yang maksimal. ${ }^{14}$

Berdasarkan beberapa penjelasan yang telah dipaparkan di atas, maka dapat dilihat bahwasannya, hasil belajar merupakan suatu yang dijadikan tolok ukur dari persentase keberhasilan dan sejauh mana ketercapaian tujuan pembelajaran yang telah dibuat oleh guru. Seorang siswa dapat di kategorikan memiliki hasil belajar yang baik apabila telah mengikuti pembelajaran dan tingkat pengetahuannya meningkat, yang otomatis diikuti dengan peningkatan sikap dari siswa.

Kasus lain terkait efektifitas belajar siswa terjadi di SMPN 2 Megaluh Jombang kelas VII, di mana para siswa kurang efektif dalam proses pembelajaran. Oleh sebab itu lembaga tersebut menerapkan metode kooperatif tipe Learning Together untuk meningkatkan efektifitas belajar siswa. Dan hasil dari penerapan tersebut aktivitas siswa lebih efektif bahkan penglolaan guru dalam proses belajar lebih efektif. ${ }^{15}$ Penerapan

\footnotetext{
13 Rahma Fatmawati, "Peningkatan Minat Belajar Siswa Dengan Menggunakan Metode Ceraamah Interaktif," Factor M 1, no. 1 (2018): 43-56.

14 Uswatun Hasanah, "Peningkatan Hasil Belajar Fiqih," Al-Tadzkiyyah: Jurnal Pendidikan Islam 8, no. 1 (2017): 1-14.

15 Rifa Nurmilah, "Efektifitas Pembelajaran Kooperatif Tipe STAD Pada Materi Pokok Perandingan di SMPN 2 Magaluh Jombang," $A l$ -
} Jurnal Intelektual: Jurnal Pendidikan dan Studi Keislaman Volume 10, Nomor 3, Desember 2020 
pembelajaran kooperatif ternyata juga efektif untuk proses pembelajaran yang menggunakan K 13, sebagaimana penelitian di SMK Al Huda Kota Kediri. Dengan metode tersebut, kognitif, afektif dan psikomotorik anak dapat berjalan dengan baik, dibuktikan dengan nilai yang tinggi, dan sikap keimanan dan ketakwaan yang meningkat. ${ }^{16}$

Selanjutnya tulisan ini akan mendeskripsikan tentang seberapa jauh efektifitas belajar siswa SMP Al Mahrusiyah Ngampel Kota Kediri ketika menerapkan metode kooperatif tipe learning together. Tempat ini dipilih, karena SMP Al Mahrusiyah Ngampel Kediri merupakan SMP berbasis pondok pesantren, sebagian besar siswa adalah santri yang menetap di asrama pesantren, dengan beragam aktifitas pesantren mulai dari pendidikan formal SMP dilanjutkan dengan kegiatan keagamaan berupa madrasah diniyah, mengaji al Qur'an, istighosah, bahtsul masail, dan kegiatan ekstra pesantren lainnya. Tentu saja kadang ada rasa lelah dan mengantuk ketika mengikuti proses pembelajaran di dalam kelas.
Metode ini diharapkan akan sangat membantu siswa-siswa supaya lebih aktif dalam mempelajari agama dan akan sangat terlihat nantinya mana yang mengabaikan dan mana yang bersungguh-sungguh dalam mempelajari mata pelajaran Pendidikan Agama Islam.

\section{Metode Penelitian}

Penelitian ini merupakan salah satu penelitian kualitatif. ${ }^{17}$ Pendekatan dalam penelitian ini menggunakan pendekatan kualitatif-deskriptif, yaitu pendekatan penelitian yang mendeskripsikan sebuah gejala, peristiwa, atau kejadian yang terjadi sekarang. Peneliti mewawancarai informan yaitu, guru mata pelajaran PAI dan mengobservasi proses pembelajaran di kelas untuk mengetahui tentang bagaimana pelaksanaan metode kooperatif tipe learning togehter dalam pembelajaran PAI di kelas VII SMP Al Mahrusiyah Ngampel Kediri.

\section{Hasil Penelitian dan Pembahasan}

Efektifitas Penggunaan Metode Learning Together dalam Pembelajaran PAI

Tahap perencanaan pembelajaran dengan menggunakan learning together

Jurnal Intelektual: Jurnal Pendidikan Dan Studi Keislaman 8, no. '1 (1 April 2018): 19-29, https://doi.org/10.33367/intelektual.v8i`1.693.

${ }^{17}$ Lexy J.Moleong, Metodologi Penelitian Kualitatif (Bandung: PT Remaja Rosdakarya, 2000). h. 4.
Khwarizmi: Jurnal Pendidikan Matematika dan Ilmu Pengetahuan Alam 4, no. 2 (2016): 141-52.

16 Bambang Priyono dan Syafik Ubaidila, "Implementasi Strategi Pembelajaran Cooperative Learning Dalam Kurikulum 2013 Mata Pelajaran Pai Kelas X Semester Genap Di SMK Al Huda Kediri," 
diskusi kelompok, yang perlu dilakukan sebelum memulai pembelajaran yaitu dengan menentukan materi pembelajaran terlebih dahulu. Berkenaan dengan itu, Syamsul Ma'arif menuturkan bahwa pada tahap ini hal pertama yang dilakukan adalah dengan "mempersiapkan terlebih dahulu materi-materi yang ada di LKS yang kita pakai, seperti saat ini kita mulai masuk pada materi Iman Kepada 10 malaikat Allah SWT. Di mana materi tersebut sudah sesuai dengan silabus dan materi tersebut memang harus kita sampaikan di kelas VII semester genap. Selanjutnya saya akan menyiapkan alat penunjang atau sarana yang diperlukan dalam proses belajar, di antaranya seperti buku LKS, absensi siswa, serta alat pendukung lainnya untuk melaksanakan metode learning together atau diskusi kelompok". ${ }^{18}$

Setelah menentukan materi yang akan diajarkan. Tahap selanjtunya adalah adalah pemilihan metode pembelajaran yang sesuai. Berdasarkan pemilihan materi yang telah dilakukan, guru memilih untuk menggunakan metode learning together atau diskusi kelompok. Untuk itu, guru membagi siswa menjadi beberapa kelompok. Teknis pembagiannya adalah, guru menginstruksikan siswa untuk berhitung secara berulang, semisal $1-5$ dan guru membagi para siswa tadi sesuai dengan kelompok diskusi sesuai dengan nomor hitung yang mereka peroleh saat berhitung tadi dan mengintruksikan agar duduk bergabung dengan masing-masing kelompok. Cara lain yang dilakukan guru untuk membagi kelompok adalah dengan membaginya berdasarkan barisan tempat duduk siswa. Misalnya ada lima baris meja dan bangku yang ditempati oleh siswa, maka kelompoknya itu 5 kelompok. Sehubungan dengan itu, Ma'arif menjelaskan bahwa "metode learning together yang diterapkan itu nanti dalam satu kelas akan dibagi menjadi beberapa kelompok dengan cara berhitung secara berulang. Setelah itu berkumpul sesuai dengan nomor urutnya ataupun mungkin nanti perderet bangku. Intinya dibagi dalam beberapa kelompok untuk mendiskusikan materi pelajaran. ${ }^{19}$

Setelah itu guru akan memberikan instruksi kepada masing-masing kelompok mengerjakan dan berdiskusi, guru juga menginstruksikan tentang ketentuan sumber materi yang boleh mereka akses seperti dari buku paket, majalah, internet atau sumbersumber lainnya. Guru juga memberikan ketentuan waktu bagi masing-masing kelompok untuk melakukan diskusi kelompok. Misalnya guru memberi batasan waktu untuk berdiskusi maksimal 20 menit.

\footnotetext{
${ }^{19}$ Ma'arif.
} 
Namun tak jarang ketika diskusi kelompok sudah dimulai, tetapi masih ada beberapa anggota kelompok yang enggan segera mengerjakan apa yang sudah dibagikan oleh ketua kelompok. Setelah itu siswa langsung mengerjakan LKS dengan kelompoknya masing-masing dengan materi iman kepada malaikat-malaikat Allah. Setiap anggota dalam kelompoknya mulai kondusif dan masing-masing individu mulai berdiskusi dan mencari jawaban yang dianggap tepat. Hal yang telah dipaparkan di atas itu sesuai dengan hasi wawancara berikut: "Sedikit cerita ya mas, setelah itu saya memberi arahan dan motivasi belajar kepada setiap kelompok untuk saling berdiskusi dan juga boleh untuk mengambil dari sumber-sumber lain. Kalau diskusinya itu biasanya saya memberi waktu 20 menit. Nah itu juga kadang ada yang bermalas-malasan, ada yang diem. Tetapi walaupun seperti itu, diskusi pun berjalan baik dan berbagai kelompok mulai mengemukakan pendapatnya, ya jadi seperti itu". ${ }^{20}$

Penjelasan di atas sejalan dengan pengamatan peneliti bahwa pada setiap kelompok memang belum secara keseluruhan menjalankan apa yang telah diarahkan guru, ada beberapa siswa juga yang pasif dalam diskusi dan mengobrol dengan anggota kelompok lain, dan juga ada yang enggan berpartisipasi dalam diskusi. Tetapi walaupun masih ada yang seperti itu, diskusi berjalan dengan baik dan sudah bisa mengemukakan pendapatnya.

Adapun hasil belajar siswa dengan penerapan metode pembelajaran learning together tampak adanya peningkatkan pada hasil belajar siswa. Hasil belajar tersebut terlihat dengan adanya peningkatan nilai para siswa setelah menggunakan metode tersebut. Para siswa mendapatkan nilai ratarata 75 ke atas. Walaupun masih terdapat beberapa siswa yang belum mencapai target sesuai dengan KKM. Akan tetapi hal tersebut berbeda dengan pembelajaran sebelumnya yaitu ketika belum menggunakan metode learning together karena banyak siswa yang nilainya belum mencapai terget. Adapun KKM mata pelajaran Pendidikan Agama Islam yaitu 68. Maka dari itu, penggunaaan metode pembelajaran learning together lebih efektif untuk meningkatkan hasil belajar. Hal ini juga sejalan dengan penuturan guru PAI bahwa "ada peningkatan yang didapat ketika siswa belajar dengan metode diskusi kelompok. Peningkatanya berbeda dengan ketika menggunakan metode yang biasa begitu, maksudnya seperti ceramah. Intinya metode yang kurang melibatkan siswa aktif, untuk masalah peningkatan itu sudah 
melebihi KKM karena KKM mata pelajaran PAI itu sebesar 68. Ternyata ketika saya menggunakan metode tersebut itu rata-rata siswa ada yang mendapatkan nilai 75 ke atas. Walaupun masih ada yang belum mencapai KKM tetapi rata-rata kebanyakan sudah mencapai”.

Dampak penggunaan metode learning together terhadap siswa kelas VII C SMP Al Mahrusiyah Ngampel Kota Kediri yaitu memberikan dampak yang baik, karena dari metode itu sendiri mengajarkan siswa agar lebih berpikir aktif, bertukar pikiran dengan teman satu kelompoknya dan juga mengutarakan pendapat, siswa-siswa mendapatkan wawasan dan pengetahuan baru karena di dalam metode ini mereka yang lebih aktif. Oleh karena itu. metode pembelajaran learning together memberi dampak baik bagi siswa. Sehubungan dengan itu, guru PAI menjelaskan bahwa: "penggunaan metode diskusi ini bisa memberikan dampak yang baik karena seperti halnya dari diskusi kelompok itu sendiri itu kan menyampaikan pendapat bisa saling menukar informasi itu secara sepintas saja kan menambah wacana dari tiap siswa. Dalam hal keorganisasian ini juga mungkin sudah terlatih di sini, nanti bagaiman ketika berdiskusi ataupun dalam menyampaikan pendapat. Kemudian dalam pemecahan masalah, secara tidak langsung dalam keorganisasian itu sudah mulai diperkenalkan atau mualai diajarkan di dalam diskusi tersebut".

Berdasarkan paparan di atas, tampak bahwa penggunaan metode pembelajaran learning together pada pembelajaran PAI pada kelas VII C dapat dikatakan baik. Ini berarti bahwa siswa maupun guru serta pihak sekolah yang berkompeten sudah baik dalam penerapannya. Indikatornya dapat dilihat dari tahapan perencanaan yang dilakukan guru dalam penerapan metode pembelajaran learning together yang maksimal. Di mana guru mempersiapkan pemilihan materi yang akan diajarakan sebagai pertimbangan untuk menentukan metode pembelajaran yang akan digunakan hingga tersusunnya RPP dan dokumen administrasi atau media pembelajaran lainnya seperti, absensi siswa, alat peraga dan sebagainya.

Dengan demikian dapat disimpulkan bahwa metode diskusi kelompok yang diterapkan oleh guru dalam mata pelajaran PAI pada materi iman kepada malaikatmalaikat Allah di SMP Al Mahrusiyah Ngampel Kota Kediri dapat dikatakan efektif. Hal tersebut karena langkah-langkah serta hal-hal yang berpengaruh dalam penerapan metode learning together telah dilaksanakan dengan maksimal. Hal tersebut membuat kegiatan belajar mengajar dengan menggunakan metode learning together 
dapat membantu mencapai tujuan pembelajaran yang lebih efektif.

Secara garis besar bisa ditarik kesimpulan bahwasanya penggunaan metode pembelajaran learning together pada pembelajaran Pendidikan Agama Islam di SMP Al Mahrusiyah Ngampel Kota Kediri sudah baik dan efektif. Faktor pendukungnya adalah, motivasi belajar guru terhadap siswa-siswa, memberikan perhatian sepenuhnya kepada siswa, dan menjaga kondisi mental siswa. Wujud keberhasilan metode ini dibuktikan dengan pencapaian hasil belajar yang sudah memenuhi nilai rata-rata yaitu, 75 walaupun masih ada beberapa siswa yang belum memenuhi kriteria ketuntasan minimum (KKM).

Adapun dampak yang timbul dari penerapan metode learning together pada siswa-siswa kelas VII C SMP Al Mahrusiyah Ngampel Kota Kediri adalah mengajarkan siswa agar lebih berpikir aktif, bertukar pikiran dengan teman satu kelompoknya dan juga mengutarakan suatu pendapat. Ini berarti penggunaan metode ini sangat memungkinkan untuk mengubah kondisi belajar siswa dari pembelajaran yang kurang aktif menjadi pembelajaran yang lebih aktif. Akan tetapi, aktifitas belajar

${ }^{21}$ Ika Setiawati, "Impelmentasi Metode Learning Together Dalam Meningkatkan Kemampuan m Membaca Intensif Siswa Kelas IV Madrasah mereka tetap berada dalam pengawasan guru sehingga guru bisa mengarahkan mereka tentang apa yang seharusnya mereka lakukan dalam diskusi kelompok. Hal ini sejalan dengan penjelasan Setiawati yang menguraikan bahwa pembelajaran yang dapat mengaktifkan siswa setidaknya harus mengacu pada beberapa kriteria berikut ini :

1. Memberi kesempatan siswa untuk berpartisipasi aktif dalam proses pembelajaran.

2. Melatih siswa untuk beragumen.

3. Metode ini memberi kemungkinan perluasaan pengetahuan.

4. Metode ini memberi kesempatan kerjasama. ${ }^{21}$

\section{Penggunaan metode learning} together sebagaimana uraian di atas dapat dibilang sebagai salah satu bentuk inovasi guru dalam mengaktifkan siswa dan mengefektifkan proses pelaksanaan pembelajaran yang berangkat dari inisiatif guru itu sendiri. Ini berarti guru tetap memainkan peran penting untuk merancang keseluruhan proses pembelajaran. Di luar itu, masih banyak hal yang dapat dieksplorasi untuk mengefektifkan pembelajaran mulai dari beragamnyaa jenis metode dan media pembelajaran. Terlebih di era digitalisasi saat ini, di mana banyak web

Ibtidaiyah Jamiyatut Tholibin Darungan Kademangan Blitar," Jural Studi Islam Al-Fikrah 3, no. 3 (2019): 1-25. 
yang menyediakan berbagai wawasan baru yang dapat diakses melalui artikel-artikel ilmiah, hasil penelitian, dan buku dalam bentuk pdf yang gratis diunduh. Selain itu, youtube juga menyediakan banyak banyak video pembelajaran yang dapat digunakan guru untuk membantu mengefektikan pembelajaran.

Dari keseluruhan tahapan pelaksanaan metode pembelajaran learning together yang telah dilakukan menunjukkan bahwa penggunaan metode ini masih sangat mungkin untuk dimaksimalkan. Hal ini mengacu pada kenyataan bahwa masih ada beberapa siswa yang belum mencapaik KKM. Meski jumlah mereka terbilang sedikit, tapi ini dapat dijadikan peluang untuk lebih memaksimalkan metode pembelajaran yang digunakan sehingga siswa akan semakin aktif belajar dan membangun pengetahuan mereka melalui diskusi kelompok. Beberapa hal yang dapat dilakukan agar metode learning together menjadi lebih efektif adalah upaya untuk lebih mengondusifkan siswa ketika presentasi kelas. Ini menunjukkan perlunya arahan lebih tentang bagaimana melakukan presentasi yang baik. Dari sini guru juga dapat memberikan pemahaman pada siswa tentang bagaimana proses atau prosedur diskusi setelah presentasi dari masingmasing kelompok karena pada tahap ini diskusi berlangsun pada skala yang lebih besar. Misalnya tentang bagaimana, menyampaikan pertanyaan, menjawab pertanyaan secara argumentatif sesuai dengan apa yang telah didiskusikan pada diskusi kelompok.

Dengan cara itu, maka akan terjadi peningkatan lebih dan pembiasaan pada diri siswa dalam membangun mental, menyatakan pendapat, menyusun argumen dan saling menerima perbedaan pendapat. Dengan cara itu, maka pembelajaran tidak hanya tertumpu pada penguasaan materi tapi juga mengarah pada pembentukan sikap ilmiah dan demokratis pada siswa.

\section{Kesimpulan}

Berdasarkan uraian tersebut yang mengacu pada hasil penelitian yang telah dilakukan pada kelas VII C di SMP Al Mahrusiyah Ngampel Kota Kediri, penulis menyimpulkan bahwasanya penggunaan metode pembelajaran learning together dalam pembelajaran PAI kelas VII C di SMP Al Mahrusiyah Ngampel Kota Kediri sudah efektif. Hal ini dibuktikan dengan peningkatan nilai rata-rata siswa yang mencapai KKM yang telah ditentukan pada mata pelajaran PAI. Di samping itu, penggunaan metode learning together juga memberikan banyak dampak positif bagi siswa yaitu, siswa menjadi lebih aktif mengikuti proses pembelajaran, lebih berani 
mengungkapkan pendapat, dan siswa dapat bertukar pengetahuan dengan temannya.

\section{Daftar Pustaka}

Agnia. "Metode Sosiodrama Berpengaruh Terhadap Motivasi Belajar Siswa." DIDAKTIKA TAUHID: Jurnal Pendidikan Guru Sekolah Dasar 4, no. 1 (2017): 1-9.

Fatmawati, Rahma. "Peningkatan Minat Belajar Siswa Dengan Menggunakan Metode Ceraamah Interaktif." Factor $M$ 1, no. 1 (2018): 43-56.

Fayakun, Muhammad. "Efektivitas Pembelajaran Fisika Menggunakan Model Kontekstual (CTL) Dengan Metodepredict, Observe, Explain Terhadap Kemampuan Berpikir Tingkat Tinggi." Jurnal Pendidikan Fisika Indonesia 11, no. 1 (Januari 2015): 49-58.

Hasanah, Uswatun. "Peningkatan Hasil Belajar Fiqih." Al-Tadzkiyyah: Jurnal Pendidikan Islam 8, no. 1 (2017): 114.

Helmi, Jon. "Penerapan Konsep Silberman dalam Metode Ceramah pada Pembelajaran PAI." AL-ISHLAH: Jurnal Pendidikan 8, no. 2 (2016): 221-45.

Hermawati, Zusi. "Peningkatan Hasil Belajar Dan Keaktifan Pada Mata Pelajaran Matematika Melalui Model Pembelajaran Learning Together Siswa Sekolah Dasar." Jurnal Pendidikan Dasar 6, no. 1 (2018): 3641.

J.Moleong, Lexy. Metodologi Penelitian Kualitatif. Bandung: PT Remaja Rosdakarya, 2000.

Laili, Nur. "Metode Learning Tournament Untuk Meningkatkan Kreativitas dan
Konseling dan Pendidikan 4, no. 2 (Juni 2016): 20-28.

Ma'arif, Syamsul. Wawancara, Kantor SMP Al Mahrusiyah, 15 Juli 2020.

Majid, Abdul. Strategi Pembelajaran. Bandung: PT Rosda Karya, 2013.

Nurmilah, Rifa. "Efektifitas Pembelajaran Kooperatif Tipe STAD Pada Materi Pokok Perandingan di SMPN 2 Magaluh Jombang." Al-Khwarizmi: Jurnal Pendidikan Matematika dan Ilmu Pengetahuan Alam 4, no. 2 (2016): 141-52.

Priyono, Bambang, dan Syafik Ubaidila. "Implementasi Strategi Pembelajaran Cooperative Learning Dalam Kurikulum 2013 Mata Pelajaran Pai Kelas X Semester Genap Di SMK Al Huda Kediri." Jurnal Intelektual: Jurnal Pendidikan Dan Studi Keislaman 8, no. `1 (1 April 2018): 19-29.

https://doi.org/10.33367/intelektual.v 8i`1.693.

Rohmawati, Afifatu. "Efektivitas Pembelajaran." Jurnal Pendidikan Usia Dini 9, no. 1 (2015): 15-32.

Saregar, Antomi. "Efektivitas Model Pembelajaran Cups: Dampak Terhadap Kemampuan Berpikir Tingkat Tinggi Peserta Didik Madrasah Aliyah Mathla'ul Anwar Gisting Lampung." Jurnal Ilmiah Pendidikan Fisika Al-BiRuNi 5, no. 2 (Oktober 2016): 234-43.

Setiawati, Ika. "Impelmentasi Metode Learning Together Dalam Meningkatkan Kemampuan Membaca Intensif Siswa Kelas IV Madrasah Ibtidaiyah Jamiyatut Tholibin Darungan Kademangan Blitar.” Jural Studi Islam Al-Fikrah 3, no. 3 (2019): $1-25$.

Sujatmika, Sigit. "Pengaruh Metode Pembelajaran Problem Based 
Analisis Efektifitas Pembelajaran Kooperatif Tipe Learning

Together pada Pembelajaran PAI di SMP Al-Mahrusiyah

Ngampel Kediri

Oleh: Rinto Arahap, Makhromi

Learning Terhadap Prestasi Belajar Ditinjau Dari Gaya Belajar Dan Kemandirian." Jurnal Sosiohumaniora 2, no. 1 (2016): 11623.

Widyanto, Prasetyo. "Penerapan Metode Pembelajaran Group Investigation Berbantuan Media Flanelgraf Untuk Meningkatkan Minat dan Hasil Belajar Siswa Pada Mata Pelajaran IPA." JPDN: Jurnal Pendidikan Dasar Nusantara 3, no. 1 (2017): 118-29.

Yamsa, Yunus. Metodologi Pengajaran Agama Islam. Jakarta: Pustaka Firdaus, 2000. 